\title{
SOSIALISASI PERGURUAN TINGGI DI DAERAH PERBATASAN TERHADAP SISWA SMA N 1 PULAU LAUT, KABUPATEN NATUNA, PROVINSI KEPULAUAN RIAU.
}

\author{
Socialization Higher Education In Border Areas Of \\ Student SMA N 1 Pulau Laut, Natuna, Riau Islands Province \\ Mahadiansar', Dhani Akbar², Mulyadi ${ }^{3}$ \\ ${ }^{1)}$ Mahasiswa Magister Administrasi Publik, Fakultas Ilmu Administrasi, \\ Universitas Brawijaya, Kota Malang \\ 2) Dosen Hubungan Internasional, Fakultas Ilmu Sosial dan Ilmu Politik, \\ Universitas Maritim Raja Ali Haji, Kota Tanjungpinang \\ 3) Alumni Mahasiswa Manajemen Sumberdaya Perairan, Fakultas Kelautan Perikanan, \\ Universitas Maritim Raja Ali Haji, Kota Tanjungpinang \\ *Korespondensi : mahadiansar@gmail.com
}

\begin{abstract}
ABSTRAK
Sosialisasi pendidikan tinggi perlu dilakukan ke daerah yang sulit untuk menjangkau akses informasi tentang perguruan tinggi dalam memberikan gambaran umum terhadap siswa Sekolah Menengah Atas (SMA) atau sederajat yang nantinya setelah lulus melanjutkan pendidikan tinggi di perguruan tinggi. Kegiatan dilaksanakan di SMA N 01 Pulau Laut, Kecamatan Pulau Laut, Kabupaten Natuna. Provinsi Kepulauan Riau. Pengabdian ini bertujuan memberikan wawasan dan informasi mengenai peranan dalam pendidikan tinggi. Sosialisasi dari tim pengabdian Universitas Maritim Raja Ali Haji mendapatkan respon yang positif oleh siswa kelas XI SMA N 1 Pulau Laut berjumlah kan 45 siswa kelas XII yang mengikuti agenda sosialisasi tersebut. Hasil dari pengabdian tim menemukan bahwa siswa SMA N 01 Pulau Laut belum pernah mendapatkan akses yang menyeluruh tentang informasi pendidikan tinggi.
\end{abstract}

Kata kunci : Sosialisasi, Pendidikan Tinggi.

\begin{abstract}
Higher education needs to be socialized to areas which minimum of information about tertiary institutions in providing a general description of high school or equivalent students who later after graduation, it is important to continue higher education in tertiary institutions. The service activities carried out at SMA N 01 Pulau Laut, Pulau Laut District, Natuna Regency, Riau Islands Province. This service aims to provide a process of planting and information about its role in higher education. The socialization from the Raja Ali Haji Maritime University community service team received a positive response from 45 students of class XII grade of SMA $N 1$ Pulau Laut. The results of the team's dedication found that SMA $N 01$ Pulau Laut students had never had comprehensive access to higher education information.
\end{abstract}

Keywords: Socialization, higher education 


\section{PENDAHULUAN}

Strategi melawan keterbelakangan adalah menyoroti paradigma pendidikan dalam proses desentralisasi menjadi semakin relevan dari peran baru yang harus dijalankan untuk memutuskan lingkaran kemiskinan, Surakhmad (2009:7). Hadirnya Perguruan Tinggi merupakan lanjutan jenjang pendidikan yang telah menyelesaikan wajib belajar 9 tahun (SMA/SMK/MA) yang dimana kehadiran perguruan tinggi mempersiapkan peserta didik untuk menjadi warga yang memiliki kemampuan akademis dan profesional yang dapat menerapkan dan mengembangkan serta memperoleh ilmu pengetahuan yang di amanatkan di dalam UU No 2 tahun 1989, pasal 16, ayat 1 . Program diploma, sarjana, magister dan spesialis maupun doktor yang diselanggarakan oleh perguruan tinggi bersifat sistem terbuka. Jenis perguruan tinggi di indonesia dapat di katagorikan dalam bentuk akademi, politeknik, sekolah tinggi dan universitas.

Keberadaan perguruan tinggi bisa menunjang generasi dalam melihat kualitas kehidupan dalam berbangsa dan bernegara. Jeffs \& Smith, (2005) pendidikan di bentuk oleh tiga faktor yang terdiri dari penekanan pada tujuan yang dicapai, lingkungan ketika belajar dan faktor pendukung lainnya (keinginan untuk menjadi pribadi yang lebih baik, kepercayaan diri, demokrasi, kejujuran dan kesamaan citacita) hal ini lebih menekankan pada faktor pembentukan karakter.

Kemudian definisi pendidikan menurut Dewey (2007) pendidikan suatu proses pembaharuan arti pengalaman, hal ini di pengaruhi didalam pergaulan sehari-hari baik orang dewasa dan orang muda yang terjadi secara sengaja yang melibatkan pengawasan dan pengembangan dari orang yang belum dewasa yang berada di lingkungannya. Usaha kesadaran bisa di laksanakan melalui pendidikan menurut
Dale (1946) yang mana melibatkan keluarga, masyarakat, pemerintah, organisasi melalui kegiatan berupa bimbingan, pengajaran dan latihan yang langsung di sekolah dan maupun di luar sekolah yang untuk mempersiapkan peserta didik agar dapat mempermainkan perannya dalam berbagai lingkungan masyarakat secara tetap untuk masa depan akan datang. Jacoby (1996) memberikan definisi bahwa sosialisasi pendidikan ini hadir untuk menawarkan kepada siswa untuk bergabung ke pengetahuan maupun keterampilan bersifat akademik dalam perguruan tinggi baik perguruan tinggi negeri maupun swasta.

Sesuai dengan penjelasan di atas kami tergerak melaksanakan kegiatan berupa pengabdian masyarakat dalam bentuk sosialisasi dengan tema "gerakan peduli pendidikan tinggi" indikator yang ingin di capai dari pengabdian ini ialah siswa SMA $\mathrm{N} 1$ Pulau Laut mendapatkan wawasan secara umum tentang pendidikan tinggi kemudian mempersiapkan diri siswa baik dari segi pendidikan karakter maupun informasi mengenai pendidikan tinggi yang ada di Kepulauan Riau, lalu terhindarnya dari sikap pesimisme untuk melanjutkan pendidikan di perguruan tinggi dan memberikan kesempatan kepada putra daerah khususnya daerah perbatasan menunjukan eksistensi dalam melanjutkan pendidikan tinggi.

\section{METODE PELAKSANAAN}

\section{Waktu dan Tempat}

Kegiatan pengabdian ini dilaksanakan selama 2 hari yang dimulai pada tanggal 14 \& 15 agustus 2018 di Kelas IX SMA N 01 Pulau Laut, Kecamatan Pulau Laut, Kabupaten Natuna, Provinsi Kepulauan Riau. (Gambar 1) 


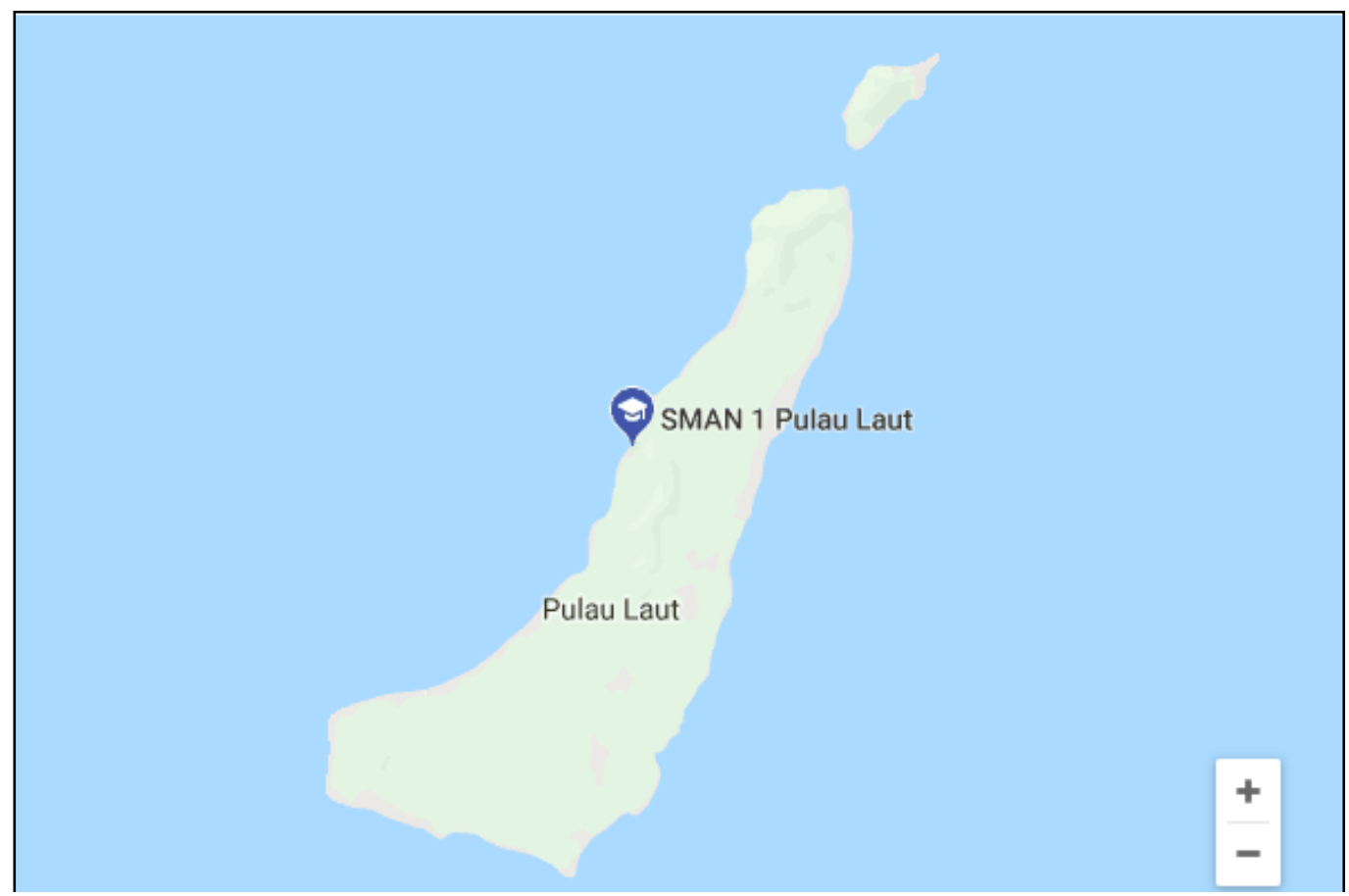

Gambar 1 Lokasi Kegiatan Pengabdian Kepada Masyarakat

\section{Teknik Pelaksanaan Kegiatan}

Metode pelaksanaan mengunakan paradigma dan pendekatan. untuk berpartisipasi dalam gerakan peduli pendidikan tinggi ada dua hal yang dapat dilakukan oleh sekolah. Pertama proses bentuk kepedulian penting adanya disosialisasikan oleh para dosen / tenaga pendidik perguruan tinggi ataupun mahasiswa dengan memberikan respon untuk menumbuhkan kepedulian yang tulus, membangun nalar obyektif dan mengembangkan persfektif secara universal pada masing-masing individu. Kedua memberikan gambaran yang mudah dicerna terhadap pendidikan tinggi yang mengarah pada peningkatan kualitas dengan mengajak para siswa agar tidak hanya sampai pada tingkat sekolah menengah atas (SMA) demi mewujudkan kecerdasan bangsa dengan menghadirkan para calon mahasiswa yang kritis dan berintelektual yang tinggi sebagai aspirasi masyarakat nantinya setelah bisa memaknai tri dharma perguruan tinggi. pernyataan tersebut sejalan dengan pendidikan yang bersifat konstruktif. Membangun semangat untuk melanjutkan pendidikan tinggi yang diberikan sebagai pengetahuan dan modal serta memberikan konsep. Apabila pengetahuan baru telah di dapatkan gambaran umum tentang perguruan tinggi yang nantinya mereka pilih, barulah siswa SMA akan menjadi pegangan kuat untuk memilih kampus yang mereka sukai sesuai dengan kemampuan dan mendapat kerangka baru tentang ilmu pengetahuan.

Samnuzulsari \& Arieta (2017:17) Secara umum ada lima prinsip dasar yang melandasi dalam sosialisasi pendidikan tinggi secara konstruktif yaitu 1) meletakan permasalahan yang relevan dengan kebutuhan siswa yang akan melanjutkan pendidikan tinggi; 2) memberikan tahapantahapan sistematik awal perkuliahan bagi mahasiswa baru nantinya jika sudah terpilih menjadi mahasiswa; 3) menghargai pilihan siswa terhadap pilihannya meskipun dampak promosi tidak sesuai keinginan pemateri sosialisasi; 4) materi sosialisasi menyesuaikan terhadap kebutuhan di daerah dan 5) menilai sosialisasi terhadap kepedulian dunia pendidikan. Adapun teknik pelaksanaan 
pengabdian dengan beberapa cara sebagai berikut :

1. Speak Up; Syah (1999) mendefinisikan ceramah sebuah metode mengajarkan dengan menyampaikan informasi dan pengetahuan secara lisan kepadda sejumlah siswa yang pada umunya mengikuti secara pasif. ceramah dilakukan dengan memberikan materi tentang gambaran dunia perkuliahan, sistem perkuliahan, aktivitas akademik dan kemahasiswaan serta institusi profil kampus itu sendiri. Ceramah dilakukan dengan menampilkan materi-materi yang aktual mengenai pendidikan tinggi. selain itu agar lebih sesuai dengan peserta sosialisasi, alat bantu seperti slide presentasi dibuat semenarik mungkin agar para siswa tidak cepat jenuh.

2. Brainstrom; Minter \& Reid (2007) mendefinisikan Brainstrom merupakan sekumpulan kelompok manusia memiliki tujuan menghasilkaan pemikiran-pemikiran yang baru dan masih segar untuk disampaikan. diskusi bersama siswa dan tim pengabdian terkait dengan kendala dan materi yang kurang paham oleh peserta sosialisasi yang sudah dibahas dalam ceramah. Diskusi ini dilakukan dengan memberikan rangsangan akan hadirnya beberpa pertanyaan-pertanyaan dari para siswa sehingga mereka bisa lebih aktif

3. Games; Monks (1982) mendefinisikan serta memandang Games sebagai pencerminan realitas sebagai bentuk awal memperoleh pengetahuan. Dengan adanya permainan yang diberikan oleh tim pengabdian, sisiwa diharapkan mampu bekerjasama untuk mengeluarkan uneg-uneg minat dan bakat serta cita-cita masa depan peserta sosiaisasi ini. Implementasi kegiatan permainan ini melalui media permainan serta memberikan imajinasi positif setelah menjadi mahasiswa bisa mewujudkan serta menyerap aspirasi masyarakat dan membanggakan kedua orang tua.

4. Team Work; Maurer (2006) mendefiniskan Team Work yang dikelola dan dilakukan sekelompok orang yang tergabung dalam sebuah wadah untuk mencapai tujuan yang telah direncanakan. Dalam hal ini sebuah kerja kelompok siswa dibagi atas dua kelompok siswa yaitu laki-laki dan perempuan dipisah. Setiap kelompok akan diberikan pertanyaan serta merefleksikan tentang materimateri sosialisasi yang telah diberikan melalui ceramah, diskusi dan permainan. Dua kelompok ini diminta menuliskan harapan dan cita-cita ketika menjadi mahasiswa dengan mendesripsikan cerita yang unik pada sebuah kertas karton berukuran 1x1 meter. Hasil kerja kelompok ini akan dipresentasikan didepan tim pengabdian. Presentasi yang menarik akan mendapatkan hadiah berupa kenang-kenangan oleh tim pengabdian.

\section{Target dan Luaran}

Kegiatan pengabdian masyarakat ini menargetkan berupa wawasan pendidikan tinggi yang dapat di pahami oleh siswa kelas SMA N 1 Pulau Laut Kabupaten Natuna. Untuk mencapai target tersebut tim berusaha menyiapkan materi dan bahan yang dibutuhkan. Materi dan bahan yang disiapkan kemudian disesuaikan dengan kebutuhan dan konteks untuk siswa kelas IX SMA N 1 Pulau laut, Kabupaten Natuna. Mengingat bahwa siswa ini adalah kelas akhir menjelang kelulusannya, maka sistem dan metode pengabdian dirancang dengan relevan dengan konteks kekinian atau generasi milinial sehingga target yang diharapkan dapat di capai dengan baik. 
Tabel 1 Fase Pelaksanaan Kegiatan

\begin{tabular}{|c|c|c|}
\hline $\begin{array}{c}\text { Tahapan Penjajagan } \\
\text { (Eksplorasi) }\end{array}$ & $\begin{array}{c}\text { Tahapan Persiapan } \\
\text { (Inisasi) }\end{array}$ & Tahapan Implementasi \\
\hline $\begin{array}{l}\text { Teknik: Observasi dan kunjungan } \\
\text { langsung ke lokasi pengabdian }\end{array}$ & Teknik: Diskusi Tim & $\begin{array}{l}\text { Teknik: Ceramah, } \\
\text { brainstroming, games, kerja } \\
\text { kelompok }\end{array}$ \\
\hline $\begin{array}{l}\text { Tujuan : menjaring informasi awal } \\
\text { tentang profil sekolah di kecamatan } \\
\text { pulau laut }\end{array}$ & $\begin{array}{l}\text { Tujuan : mendesain sistem dan } \\
\text { model pengabdian }\end{array}$ & $\begin{array}{l}\text { Tujuan : Memberikan } \\
\text { pemahaman secara garis besar } \\
\text { pentingnya Perguruan Tinggi }\end{array}$ \\
\hline $\begin{array}{l}\text { Waktu : hari kedua di kecamatan } \\
\text { pulau laut }\end{array}$ & $\begin{array}{l}\text { Waktu : hari ketiga dikecamatan } \\
\text { pulau laut }\end{array}$ & $\begin{array}{l}\text { Waktu : hari keempat dan ke } \\
\text { lima di SMA N } 1 \text { Pulau Laut, } \\
\text { Kabupaten Natuna }\end{array}$ \\
\hline
\end{tabular}

Kemudian luaran yang diharapkan dapat memahami secara umum kriteria perguruan tinggi sesuai minat dan bakat, lalu perubahan cara berfikir dalam mempersiapkan serta memahami kondisi yang akan terjadi saat memulai atau diterima dalam perguruan tinggi serta para siswa mampu mempromosikan / menjelaskan kepada orang tua ataupun masyarakat tentang pentingnya melanjutkan pendidikan tinggi setelah lulus nantinya dalam lingkungannya sehari-hari.

\section{Alur Pelaksanaan Kegiatan}

Tim pengabdian Universitas Maritim Raja Ali Haji melakukan tahapan tahapan pelaksanaan pengabdian sesuai dengan metode pengabdian yang pada umum nya memiliki konsep dalam pelaksanaannya berupa fase pelaksanaan kegiatan (Tabel 1)

\section{HASIL DAN PEMBAHASAN}

\section{Pelaksanaan Kegiatan Sosialisasi}

Kegiatan bersifat pengabdian ini dimulai dengan menanyangkan beberapa media bahan presentasi berupa Power Point Text (PPT). Hal ini bertujuan untuk menciptakan ketertarikan para siswa terhadap kegiatan pengabdian. Setelah itu kegiatan dilanjutkan dengan memaparkan gambaran umum perguruan tinggi di indonesia kepada para siswa. Presentasi disampaikan im pengabdian Universitas Maritim Raja Ali Haji. Tim inimemaparkan definisi, perguruan tinggi yang ada di kepulauan riau, mengali informasi perguruan tinggi, dan cara memberikan tips-tips bantuan biaya pendidikan atau beasiswa dari pihak swasta maupun Pemerintah. Tim Pemateri memaparkan bahwsanya pentingnya melanjutkan peguruan tinggi setelah menyelesaikan sekolah sederajat (SMA/SMK) bagi siswa dan harus bekal serta persiapan yang harus di miliki oleh siswa. Sosialisasi dalam bentuk presentasi dibuka sesi diskusi sebagai sarana untuk brainstorming dengan siswa/peserta kegiatan. Dari hasil diskusi diketahui bahwa banyak siswa yang belum memahami pentingnya melanjutkan jenjang yang lebih tinggi / masuk perguruan tinggi. Pada umumnya, pertanyaan-pertanyaan para siswa terkait dengan kendala-kendala serta membuka wawasan untuk berkuliah yang menjadi eksistensi setiap tahun ketika siswa sederajat telah menyelesaikan studinya. 
Tabel 2 Daftar Perguruan Tinggi di Kepulauan Riau

\begin{tabular}{|c|c|c|}
\hline No & Nama Perguruan Tinggi & Lokasi \\
\hline 1 & Universitas Maritim Raja Ali Haji & Kota Tanjungpinang \\
\hline 2 & Politeknik Negeri Batam & Kota Batam \\
\hline 3 & Universitas Putera Batam & Kota Batam \\
\hline 4 & Universitas Batam & Kota Batam \\
\hline 5 & Universitas Riau Kepulauan & Kota Batam \\
\hline 6 & Universitas Karimun & Kabupaten Karimun \\
\hline 7 & Politeknik Pariwisata & Kota Batam \\
\hline 8 & Sekolah Tinggi Ilmu Sosial dan Ilmu Politik Raja Haji & Kota Tanjungpinang \\
\hline 9 & Sekolah Tinggi Ekonomi Pembangunan & Kota Tanjungpinang \\
\hline 10 & Sekolah Tinggi Teknik Batam & Kota Batam \\
\hline 11 & Sekolah Tinggi Teknik Bentara Persada & Kota Batam \\
\hline 12 & Sekolah Tinggi Teknik Ibnu Sina & Kota Batam \\
\hline 13 & Sekolah Tinggi Teknologi Indonesia & Kota Tanjungpinang \\
\hline 14 & Sekolah Tinggi Ilmu Ekonomi & Kota Batam \\
\hline 15 & Sekolah Tinggi Ilmu Ekonomi Bentara Persada & Kota Batam \\
\hline 16 & Sekolah Tinggi Ilmu Ekonomi Ibnu Sina & Kota Batam \\
\hline 17 & $\begin{array}{l}\text { Sekolah Tinggi Manajemen Informatika dan Komputer Putera } \\
\text { Batam }\end{array}$ & Kota Batam \\
\hline 18 & Sekolah Tinggi Ilmu Kesehatan Hang Tuah & Kota Tanjungpinang \\
\hline 19 & $\begin{array}{l}\text { Sekolah Tinggi Ilmu Komunikasi International Gurindam } \\
\text { Archipelago }\end{array}$ & Kota Tanjungpinang \\
\hline 20 & Sekolah Tinggi Katolik Bentara Persada & Kota Tanjungpinang \\
\hline 21 & Sekolah Tinggi Teologi Calvary & Kota Batam \\
\hline 22 & Sekolah Tinggi Teologi Injili Indonesia & Kota Batam \\
\hline 23 & Sekolah Tinggi Keguruan dan Ilmu Pendidikan Al-Fayed & Kota Batam \\
\hline 24 & Sekolah Tinggi Pariwisata Sahid Bintan & Kabupaten Bintan \\
\hline 25 & Sekolah Tinggi Ilmu Kesehatan Karimun & Kabupaten Karimun \\
\hline 26 & Sekolah Tinggi Ilmu Ekonomi Cakrawala & Kabupaten Karimun \\
\hline 27 & Sekolah Tinggi Ilmu Sosial dan Ilmu Politik Bunda Tanah Melayu & Kabupaten Lingga \\
\hline 28 & Politeknik Bintan Cakrawala & Kabupaten Bintan \\
\hline 29 & Akademi Akuntansi Tanjung Pinang & Kota Tanjungpinang \\
\hline 30 & Akademi Kebidanan Anugerah Bintan Tanjungpinang & Kota Tanjungpinang \\
\hline 31 & Akademi Bahasa Asing Putera Batam & Kota Batam \\
\hline 32 & Akademi Bahasa Asing Tanjung Pinang & Kota Tanjungpinang \\
\hline 33 & Akademi Keperawatan Angkatan Laut & Kota Tanjungpinang \\
\hline 34 & Akademi Keperawatan Mitra Bunda Persada & Kota Tanjungpinang \\
\hline 35 & Akademi Keperawatan Griya Husada & Kota Batam \\
\hline
\end{tabular}

Kegiatan dilanjutkan dengan permainan (games) yang dilakukan dengan melibatkan seluruh peserta kegiatan. Adapun games yang diberikan adalah permainan tebak nama perguruan tinggi di Kepulauan Riau. Prosesi permainan ini dipandu oleh mahasiswa yang dilibatkan dalam kegiatan ini. Permainan ini dilakukan dengan cara meminta kepada beberapa anak yang melakukan tebakan yang mengetahui berapa banyak perguruan tinngi yang ada di kepulauan riau. Peserta sosialisasi yang menjawab lebih dari 5 peguruan tinggi akan mendapatkan hadian berupa buku dan stiker perguruan tinggi dari pemandu games. Hal ini merefleksikan siswa sejauh mana siswa mengetahui keberadaan pegruruan tinggi di kepulauan riau. buku di berikan kepada pemenang sebagai bentuk literasi baca agar lebih banyak membaca dan stiker terssebut sebagaimana untuk kenang-kenangan bahwasanya tim pengabdian universitas maritim raja ali haji telah melaksanakan program pengabdian sosialisasi. Data terbaru yang tim pengabdian miliki sebanyak 35 Perguruan 
Tinggi baik swasta ataupun negeri yang meliputi, politeknik, sekolah tinggi, universitas, politeknik dan akademi yang ada di Kepulauan Riau (Tabel 2).

Para siswa sangat seirus dalam mengikuti tebak nama pereguraun tinggi di kepulauan riau. Selain merupakan hal yang baru bagi mereka, permainan ini juga sangat menyenangkan untuk mereka. Hal ini terlihat dari keceriaan yang mereka tunjukkan saat permainan berlangsung .Sebagaimana diketahui, sistem pendidikan di Indonesia sangat berorientasi pada pengembangan kemampuan kognitif siswa melalui penciptaan kurikulum yang yang rigid dan sistem pembelajaran yang tidak humanis. Melalui permainan tebak nama kampus para siswa diberikan pemahaman mengenai serta sejauh mana mengerahui peguruan tinggi tersebut dan metode yang lebih interaktif dan dinamis. Hal ini bertujuan agar para siswa tidak merasa cepat bosan dan memudahkan para siswa untuk menyerap untuk berfikir. Setelah permainan usai, kegiatan dilanjutkan dengan makan siang bersama dan sholat zuhur. Kemudian kegiatan dilanjutkan dengan kerja kelompok.

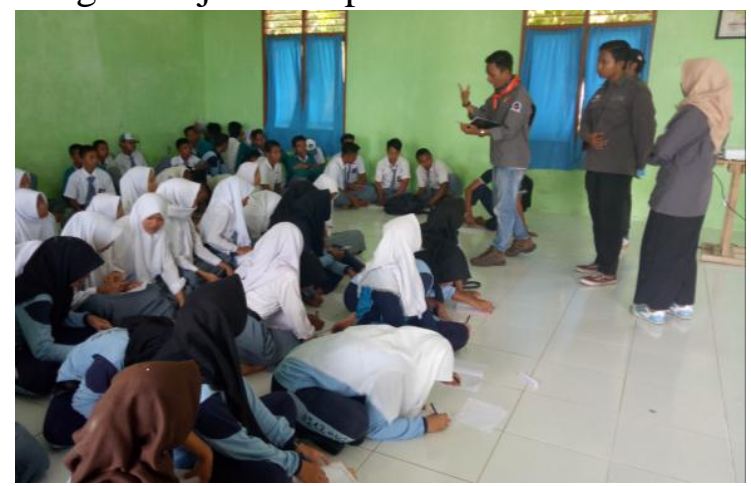

Gambar 2 Sosialisasi (Games) Perguruan Tinggi di Kelas XI SMA N 1 Pulau Laut, Natuna

Para siswa dibagi menjadi tujuh kelompok, dimana setiap kelompok beranggotakan 5 orang siswa. Setiap kelompok diminta untuk menggambar apapun yang terkait dengan cita-cita mereka. Gambar tersebut dibuat di kertas ukuran $1 \mathrm{~m} \quad \mathrm{x} \quad 1 \mathrm{~m}$. Setiap kelompok dilengkapi dengan peralatan menggambar, seperti pena, pensil, pensil warna, dan spidol. Setiap siswa diminta untuk bekerjasama dalam kelompoknya agar menghasilkan tulisan dengan keinginan cita-cita untuk masa yang akan datang. gambar yang menarik dan relevan dengan yang diperintahkan. Setelah selesai menggambar, setiap kelompok diminta mempresentasikan hasil ide dan citacitanya di depan kelas, sedangkan siswa yang lain diminta untuk menanggapi. Para siswa tidak kalah antusiasnya mengikuti kegiatan ini dibandingkan permainan yang pertama. Dari kegiatan ini terlihat bahwa para siswa memiliki imajinasi yang mengagumkan dalam melihat tatanan masa depan mereka.

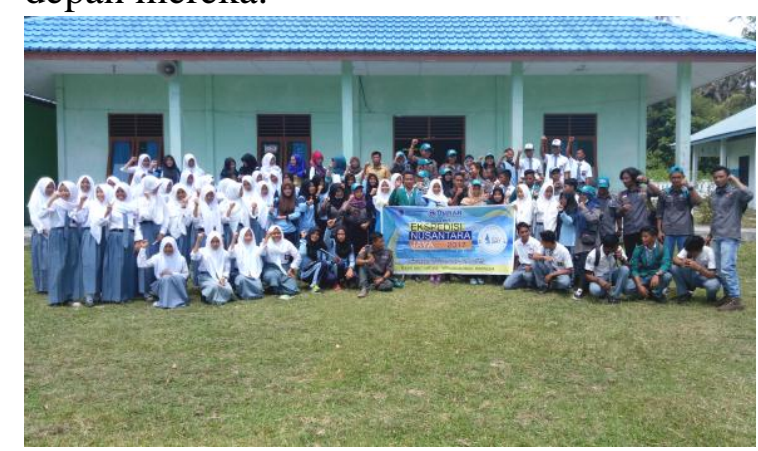

Gambar 3 Foto Bersama Kelas IX SMA N 1 Pulau Laut, Natuna

Dalam presentasi kelompok, setiap kelompok menunjuk salah seorang perwakilannya untuk mempresentasikan hasil karya temen-temen satu kelompok. Rata-rata gambar yang dibuat oleh setiap kelompok merepresentasikan cita-cita yang sebagaimana mereka memiliki impian yang luas. Hal ini wajar karena di tingkat daerah sangat minim akan tercapai nya cita-cita tersebut dikarenakan serba keterbatasan mulai dari ekonomi, akses fasilitas daerah serta sistem informasi daerah yang belum menyampai akses ke daerah terpecil. Peserta yang lain 
diperbolehkan memberikan respon yang beragam terhadap cita-cita dan masa depan. Dari respon tersebut diketahui bahwa mayoritas siswa sepakat cita-cita adalah masa depan yang harus di raih untuk mewujudkan kesejahteraan bagi bangsa dan negara. Para siswa juga berkomitmen untuk mengikuti perkembangan informasi mengenai perguruan tinggi baik tingkat daerah, nasional maupun internasional yang nantinya akan mampu bersaing dengan yang lainnya sebagai anak daerah perbatasan.

Kerja kelompok ini dimaksudkan untuk melatih kemampuan siswa bekerja sama dalam tim (team work), kebebasan, saling menghargai, disiplin, dan tanggung jawab. Para siswa diberikan kebebasan untuk menuangkan apa saja yang ada di dalam pikirannya, dalam bentuk gambar terkait dengan cita-cita dan masa depan. Selama ini para siswa tersebut sebenarnya sudah memiliki stok pengetahuan mengenai citacita dan masa depan. Dengan permainan ini mereka mendapatkan wadah untuk menyalurkan ide-ide dan pengetahuannya tersebut. Media menggambar yang digunakan dalam penelitian ini melawan arus utama sistem pendidikan kita yang lebih banyak menceramahi siswa. Dalam metode ini siswa bebas menuangkan gagasannya, menuliskannya, dan mempresentasikannya sendiri. Siswa diajak untuk belajar dari diri sendiri, pengalaman orang lain, dan realitas yang mereka alami sendiri.

\section{Promosi Universitas Maritim Raja Ali Haji}

Pendidikan merupakan usaha-usaha yang sengaja dipilih untuk mempengaruhi dengan tujuan peningkatan keilmuan, jasmani dan akhlak sehingga secara bertahap dapat mengantarkan pesserta didik kepada tujuannya pailing tinggi, Yusuf (1978). Tim Pengabdian berkesempatan mempromosikan kampus yang berstatus Perguruan Tinggi Negeri (PTN). Salah satu dari pemateri memaparkan mulai dari sejarah Univerisitas Maritim Raja Ali Haji (UMRAH). Saat ini UMRAH memiliki 5 fakultas dan 19 program studi yang akan di peruntukan kepada siswa yang telah dinyatakan lulus dari Sekolah sederajatnya (SMA/SMK). Pemateri menjelaskan kepada siswa sosialisasi berbagai jalur masuk pendaftaran di UMRAH yang terdiri dari :

1. Seleksi Nasional Masuk Perguruan Tinggi Negeri (SNMPTN) yaitu diselenggarakan sebagai pengganti SNMPTN Jalur Undangan, merupakan pola seleksi nasional berdasar pada nilai rapor dan prestasi lainnya.

2. Seleksi Bersama Masuk Perguruan Tinggi Negeri (SBMPTN) yaitu secara teknis sama dengan SNMPTN Jalur Ujian Tulis 2012, merupakan pola seleksi nasional berdasarkan hasil tes tertulis/ujian keterampilan

3. Seleksi Mandiri Masuk Perguruan Tinggi Negeri (SMM-PTN) Wilayah Barat yaitu diselenggarakan semenjak 2017 sebagai Jalur Mandiri Bersama Perguruan Tinggi Negeri Wilayah Barat

4. Mutiara UMRAH yaitu merupakan Jalur Seleksi Mandiri Mahasiswa Baru berdasarkan Portofolio Calon Mahasiswa

5. Kelas Paralel UMRAH yaitu Jalur Mandiri Penerimaan jenjang Sarjana untuk Para pekerja/Karyawan untuk prodi S1 Ilmu Hukum, S1 Akuntansi, S1 Manajemen.

Respon dari peserta sosialisasi cukup serius mendengarkan pemaparan dari pemateri tim pengabdian UMRAH di karenakan mayoritas saat di tanya berkeinginan kuat untuk mendaftar ke Universitas Maritim Raja Ali Haji. Berbagai alasan mereka ungkapkan oleh peserta soisalisasi di antaranya akses masih 
terjangkau di daerah provinsi kepulauan riau kemudian ada yang memilih jalur yang bersifat mudah seperti jalur mutiara yang memungkinkan mudah di terima di kampus negeri tersebut. Tidak hanya itu pemateri juga memberikan materi tentang beasiswa yang ada di Universitas Maritim Raja Ali Haji yang bisa membantu siswa tersebut jikala mengalami kendala perekonomian atau keberatan dalam membayar biaya semester atau di sebut dengan Uang Kuliah Tunggal (UKT), pemateri juga menjelaskan kepada siswa bermacam-macam beasiswa yang bisa di raih, diantaranya Beasiswa Pendidikan Miskin (BIDIMISI), Beasiswa Peningkatan Prestasi Akademik (PPA), Beasiswa Bantuan Belajar Mahasiswa (BBM), Beasiswa Daerah dan Swasta serta banyak beasiswa yang bisa di raih bagi mahasiswa baru.

Mendengar pemaparan beasiswa tersebut, peserta sosialisasi merasa optimis dan tidak ragu ingin melanjutkan ke jenjang perguruan tinggi, hal ini di sebabkan memang para siswa kurang mendapatkan informasi secara mendalam. Namun, setelah kegiatan pengabdian selesai sesuai target yang di laksanakan oleh tim pengabdian yang terdiri dari ceramah, diskusi, games, dan kerja kelompok dilakukan, wawasan para siswa menjadi semakin bertambah. Cara pandang mereka pun jauh lebih advance dari sebelumnya. Hal ini menunjukkan bahwa metode yang dipilih cukup cocok dengan situasi dan kebutuhan mereka.

\section{KESIMPULAN}

Tim pengabdian telah melakukan evaluasi kegiatan, dari empat jenis kegiatan yang dilaksanakan di SMA N 1 Pulau Laut disimpulkan bahwa kegiatan ini sudah mencapai hasil yang diinginkan.
Sebagaimana tujuan kegiatan ini, maka para siswa yang telah mengikuti kegiatan ini sudah memahami gambaran umum masuk perguruan tinggi yang ditransfer kepada para siswa. Evaluasi dilakukan dengan membandingkan kondisi sebelum dan sesudah kegiatan pengabdian ini dilakukan. Sebelumnya, para siswa belum memahami secara komprehensif tentang perguruan tinggi. Mayoritas dari mereka masih memandang bahwa perguruan tinggi hanya yang mampu dari faktor ekonomi dan faktor lingkungan. Selain itu, banyak dari mereka yang belum mengetahui informasi penerimaan mahasiswa baru bagi yang lulus SMA dan bagaimana cara mencari informasi tersebut. Namun, setelah kegiatan ceramah, diskusi, permainan, dan kerja kelompok dilakukan, wawasan para siswa menjadi semakin bertambah.

Cara pandang mereka pun jauh lebih advance dari sebelumnya. Hal ini menunjukkan bahwa metode yang dipilih cukup cocok dengan situasi dan kebutuhan mereka. Sebagaimana yang telah dijelaskan sebelumnya bahwa kegiatan ini bertujuan membuka cara pandang kepada siswa-siswa terhadap pentingnya melanjutkan pendidikan tinggi merupakan proses meningkatkan kapasitas intelektual muda di dunia akademisi yang berkelanjutan sehingga membutuhkan waktu untuk memilih yang cocok sesuai impian dan cita-cita para siswa kelas XI SMA N 1 Pulau laut. Mengingat bahwa dunia pendidikan tinggi ini harus memberikan perhatian khusus serta kesempatan untuk anak daerah di perbatasan mengikuti atau berpartisipasi melanjutkan pendidikan yang lebih tinggi. namun kegiatan ini dapat menjadi langkah awal untuk lebih mempromosikan perguruan tinggi di daerah-daerah perbatasan atau terdepan yang ada di provinsi kepulauan riau. 


\section{DAFTAR PUSTAKA}

Dale, E. (1946). Audiovisual Methods in Teaching. United States America: Dryden Press.

Dewey, J. (2007). The School and Society. America: Cosimo Classics.

Jacoby, B. (1996). Service-Learning in Higher Education: Concepts and Practices. San Francisco: Jossey-Bass Inc.

Jeffs, T., \& Smith, M. (2005). Informal Education: Conversation, Democracy, and Learning. Educational Heretics Press.

Maurer, T. (2006). Cheerleading Skills. United States America: Rourke Pub.

Minter, D., \& Reid, M. (2007). Lightning in a Bottle: The Proven System to Create New Ideas and Products. Chicago: Sourcebooks.
Monks, F. J. (1982). Psikologi Perkembangan: Pengantar dalam berbagai bagiannya. Yogyakarta: Gadjah Mada Press.

Samnuzulsari, T., \& Arieta, S. (2017). Ipteks Bagi Masyarakat: Penguatan Pendidikan di Sekolah. (W. E. Yudiatmaja, Ed.). Tanjungpinang: Umrahpress.

Surakhmad, W. (2009). Filosofi Pendidikan: Menemukan Kembali Landasan yang Hilang. In Pendidikan Nasional, Strategi, dan Tragedi (pp. 29-89). Jakarta: Buku Kompas.

Syah, M. (1999). Psikologi Pendidikan dengan Pendekatan Baru. Bandung: Remaja Rosdakarya.

Yusuf, M. (1978). Pokok-Pokok Pendidikan dan Pengajaran. Jakarta: Hidakarya Agung.

Diterima : 18 September 2019

Disetujui : 11 November 2019 